\title{
EHMTI-0221. Tension type headaches and chronic pain syndrome
}

\author{
HR Vekilyan 1*, AA Karapetyan², AH Karapetyan', EM Gevorgyan', HM Manvelyan \\ From 4th European Headache and Migraine Trust International Congress: EHMTIC 2014 \\ Copenhagen, Denmark. 18-21 September 2014
}

\section{Introduction}

Tension type headaches (TTH) are the most common forms of primary headaches. The prevalence of TTH is about $80 \%$ among cephalgic pain.

\section{Aims}

The aim of study was investigation of intercoupling of TTH and chronic pain syndrome (CPS).

\section{Methods}

Method Questionnaires on screening of headaches (according to recommendations of International Headache Society) were blindly distributed among 3000 people in the country. 603 (458 women/ 145men) patients were selected for the study with primary headaches (migraine, tension type and cluster headache). Age of participants was $42 \pm 16$ years.

\section{Results}

Data analysis revealed that 387 patients $(64,2 \%)$ (107 males and 280 females) suffer of TTH, 204 migraine (33, 8\%) (36 males and 168 females), 12 (2\%) (8 males and 4 females) cluster headache. The coincidence with CPS was revealed in 232 patients with TTH $(60 \%)$ and in 40 patients with migraine (20\%).

\section{Conclusions}

Our data reveal non significant difference of distribution of primary headaches in Armenia, but it shows that CPS is present in more cases of chronic TTH and/or combination of TTH with other primary headaches. Further investigation on simultan CPS and TTH must be continued, as both could have common mechanisms and development, as well treatment options.

No conflict of interest.

${ }^{1}$ Neurology, Yerevan State Medical University, Yerevan, Armenia

Full list of author information is available at the end of the article
Authors' details

${ }^{1}$ Neurology, Yerevan State Medical University, Yerevan, Armenia. ${ }^{2}$ Family Medecine, Yerevan State Medical University, Yerevan, Armenia.

Published: 18 September 2014

doi:10.1186/1129-2377-15-S1-C62

Cite this article as: Vekilyan et al.: EHMTI-0221. Tension type headaches and chronic pain syndrome. The Journal of Headache and Pain 201415 (Suppl 1):C62.

\section{SpringerOpen ${ }^{\circ}$}

(c) 2014 Vekilyan et al; licensee Springer. This is an Open Access article distributed under the terms of the Creative Commons Attribution License (http://creativecommons.org/licenses/by/2.0), which permits unrestricted use, distribution, and reproduction in any medium, provided the original work is properly cited.
Submit your manuscript to a SpringerOpen ${ }^{\circ}$ journal and benefit from:

- Convenient online submission

- Rigorous peer review

- Immediate publication on acceptance

- Open access: articles freely available online

- High visibility within the field

- Retaining the copyright to your article

Submit your next manuscript at $\mathbf{s p r i n g e r o p e n . c o m ~}$ 